\title{
Imaginarios racializados
}

y clasificación social: retos para el análisis cultural (y pistas para evitar una deriva decolonial esencialista)

\section{Sergio Caggiano ${ }^{1}$}

Recepción: 19 de mayo de 2015 / Aprobación: 8 de julio de 2015

\section{Resumen}

El artículo aborda retos al estudio de los imaginarios y los sistemas de clasificación, así como sus potencialidades para comprender las desigualdades sociales. Analiza una disputa en torno a la presencia indígena en la historia y el presente de Argentina; más precisamente, imágenes visuales correspondientes a "repertorios hegemónicos" (manuales escolares y un álbum de fotografías históricas) y "repertorios alternativos" (principalmente sitios de Internet de organizaciones indígenas), que ofrecen explícitamente una mirada diferente. El artículo subraya la relevancia histórica y contemporánea de la racialización y la raza en tanto mecanismo y patrón de clasificación y categorización social. Reconociendo los aportes de la perspectiva decolonial a esta problemática, advierte sobre los riesgos de lo que presenta como una "deriva decolonial esencialista", que se origina en encontrar el sustrato de la raza no ya en la biología o en la cultura, sino en una comprensión esencializada de la historia.

\section{Palabras clave}

Imaginarios; clasificación social; raza; perspectiva decolonial; Argentina

\section{Abstract}

This article approaches some challenges of studies on imaginaries and classification systems, and their potentialities to understand social inequalities. It analyzes a dispute over the indigenous presence in the history and present of Argentina, more precisely, it works on visual images belonging to "hegemonic repertories" (textbooks and an album of historic photographs) and to "alternative repertoires" (mainly websites of indigenous organizations), which offer explicitly a different gaze. The article highlights the historical and contemporary relevance of racialization and race, as mechanism and pattern of social classification and categorization. Recognizing the contributions of the decolonial perspective to this problem, it warns of the risks of what is presented as an "essentialist decolonial drift", which originates on finding the substrate of race no longer in biology or culture, but in an essentialized understanding of history.

$1 \quad$ Argentino. Doctor en Ciencias Sociales por la Universidad Nacional de General Sarmiento. Investigador en el Centro de Investigaciones Sociales (CIS)- Consejo Nacional de Investigaciones Científicas (CONICET) / Instituto de Desarrollo Económico y Social (IDES), Buenos Aires y Director del Doctorado en Comunicación, Facultad de Periodismo y Comunicación Social (FPyCS), Universidad Nacional de La Plata (UNLP), La Plata. Correo electrónico: sergio.caggiano@gmail.com 


\section{Keywords}

Imaginaries; social classification; race; decolonial perspective; Argentina

\section{Resumo}

O artigo aborda desafios para o estudo dos imaginários e os sistemas de classificação, bem como as suas potencialidades para a compreensão das desigualdades sociais. Analisa uma disputa sobre a presença indígena na história e no presente da Argentina, mais precisamente imagens visuais que pertencem aos "repertórios hegemónicos" (livros de texto e um álbum de fotografias históricas) e aos "repertórios alternativos" (principalmente sítios de Internet de organizações indígenas), que explicitamente fornecem um olhar diferente. O artigo destaca a relevância histórica e contemporânea da raça e da racialização como mecanismo e padrão de classificação e categorização social. Reconhecendo as contribuições da perspectiva decolonial para esta problemática, alerta sobre os riscos do que é apresentado como uma "deriva decolonial essencialista", que se origina em encontrar o substrato da raça não já na biologia ou na cultura, mas em uma compreensão essencializada da história.

\section{Palavras chave}

Imaginários; classificação social; raça; perspectiva decolonial; Argentina

\section{Introducción. Imaginarios, clasificación social y desigualdades}

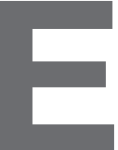

ste artículo trata sobre imaginarios y procesos de clasificación social, con el presupuesto teórico de que ellos están íntimamente vinculados con la dinámica de las desigualdades. Las disputas en torno a los imaginarios sociales atañen directamente a las luchas por reconocimiento, entendiéndolas en toda su complejidad material y política², es decir, en su carácter de "reclamos de justicia" (Canessa, 2012, p. 24). En este sentido, asumo que sin la comprensión de los imaginarios ${ }^{3}$ y sus tensiones no es posible entender aspectos cruciales de las luchas por ampliar o reducir las desigualdades.

2 Sin poder reponer aquí un muy largo debate, aludo a las polémicas filosóficas entre Iris Marion Young, Nancy Fraser, Judith Butler y Axel Honneth (Young, 1990; Honneth, 1995; Fraser, 1997 y 2000; Butler, 2000; Fraser y Honneth, 2003), que dieron cuenta de la materialidad y politicidad de las luchas por reconocimiento, sea porque se advierta que en sí mismo el reconocimiento afecta a la injusticia o a la opresión, sea que se lo considere un aspecto sin el cual las luchas por redistribución no pueden tener plena consistencia o sea que se lo considere el horizonte último de toda lucha sociopolítica.

3 Tomo "imaginario", en general, en el sentido en que lo trabajó Baczko (1999), y recupero también algunas indicaciones para estudiar el proceso de "imaginación social", que para Appadurai combina la idea de representaciones en el sentido durkheimiano, la idea más habitual de las imágenes como producciones visuales y la que está presente en usos adjetivados como el de "comunidad imaginada" (Appadurai, 2001, p. 44 y ss.). 
Es en la dinámica sociocultural y política que ciertas posiciones sociales se perciben y experimentan como injustas y ciertas relaciones como asimétricas, o bien se interpretan como asimetrías tolerables o legítimas. Los sistemas de clasificación social y las categorías (nacionales, de clase, raciales, de género, étnicas, etarias, sindicales, políticas u otras) de reconocimiento (o desconocimiento) de los otros juegan un papel crucial en estas disputas, en las que está en juego el sentido mismo que adquirirá aquello por lo que se lucha y las identificaciones de quienes lo hacen. Estos sistemas clasificatorios y categorías son un componente clave de la matriz o rejilla de lectura en base a la cual se determina la posición de actores y grupos sociales respecto de las asimetrías, desigualdades y jerarquías y, en el mismo proceso, son definidas como tales esas asimetrías, desigualdades y jerarquías (Ortner, 2006)4.

Procuraré mostrar, con un análisis concreto, retos al estudio de los imaginarios y los sistemas de clasificación, así como sus potencialidades para aproximarnos a la reconfiguración de las desigualdades. Más precisamente, presentaré materiales de una disputa a propósito de la presencia de los pueblos indígenas en la historia y el presente de Argentina. Uno de los objetivos que persigo es subrayar la relevancia histórica y contemporánea de la racialización y la raza en el contexto nacional y regional, en tanto mecanismo y patrón de clasificación y categorización social. Dado que los procesos de racialización y su producto, la raza, han estado comúnmente opacados en las tradiciones intelectuales latinoamericanas, el señalamiento de su importancia ha sido uno de los aportes de la perspectiva decolonial y, al mismo tiempo, uno de sus puntos débiles. Un segundo objetivo de este trabajo es, entonces, advertir sobre los riesgos de lo que propongo llamar "deriva decolonial esencialista", que se origina en encontrar el sustrato de la raza no ya en la biología o en la cultura, sino en una comprensión esencializada de la historia.

\section{Procesos de clasificación y categorías sociales}

La definición de las diferencias y las desigualdades, así como de las posiciones que podrá ocupar cada quien respecto de ellas y de los criterios para hacerlo, se abre parcialmente a la hora en que las personas deciden reunirse, proyectar intereses comunes y acciones conjuntas. En ese momento se pone en juego el sentido mismo que adquirirá aquello por lo que se lucha y aquellos que luchan, ya que es en el desarrollo de la contienda que se definirán sus protagonistas (Thompson, 1989), que se establecerán los reclamos propios y se

4 Desde luego, los procesos de clasificación no ocurren en el vacío ni en abstracto. Actores sociales sindicales, religiosos, empresariales, territoriales, étnicos y otros, que van desde movimientos u organizaciones locales hasta organizaciones transnacionales o corporaciones globales y organismos internacionales, en diálogo con dependencias estatales y entidades supranacionales, luchan por imponer unas (u otras) clasificaciones sociales, que impactarán en la reducción o ampliación, impugnación o legitimación de las desigualdades, en los modos de medirlas y, antes, de definirlas, y para hacerlo intervienen a distinta escala y sobre distintos mecanismos de producción o reproducción de las mismas. 
reconocerán o desconocerán los ajenos. Es en ese proceso que se percibirán e interpretarán las justicias y las injusticias, las paridades y las asimetrías.

Las condiciones de existencia complejas y cambiantes que experimentan las personas ofrecen diferentes vías por las cuales participar del proceso, comprender sus posiciones y relaciones sociales y ordenar sus prácticas en relación con otros. La definición de diferencias, desigualdades y posiciones a ocupar en relación con ellas se da en el marco de "sistemas de presentación" (Hall, 1998, p. 11), es decir, de imaginarios sedimentados históricamente que ponen límites y presiones (Williams, 2000) a los deseos y a las aspiraciones, a lo que podemos concebir como aquello que nos corresponde o, por el contrario, que no nos es posible reivindicar. De lo anterior se desprende el papel crucial que juegan las categorías con las cuales las personas viven y experimentan las posiciones y relaciones sociales (Hall, 2003).

Las categorías son a la vez el resultado de los procesos de clasificación social y el sostén sobre el que esta clasificación se apoya (Bourdieu, 1982 y 1990), y son fundamentales "porque sus límites hacen un crucial trabajo organizacional” (Tilly, 2000, p. 20). En el mundo humano, "clasificación es organización” (Douglas y Hull, 1992, p. 11). Las categorías sociales, entonces, forman parte de nuestra vida cotidiana y la afectan profundamente; no constituye una hipérbole afirmar que los humanos "actuamos y pensamos dentro de ellas" (Starr, 1992, p. 155).

Quién pertenece y quién no a una nación, por ejemplo, o al espacio o unidad sociopolítica de que se trate, o de qué manera se pertenece a ella, nos habla no solo de inclusiones y exclusiones, sino de desigualdades, asimetrías y jerarquías, de los procedimientos para legitimar estas relaciones o para "naturalizarlas". Charles Tilly señaló que las categorías sociales y las "diferencias categoriales como negro/blanco, varón/mujer, ciudadano/extranjero o musulmán/judío" (Tilly, 2000, p. 21) son un factor clave en la explicación de la existencia y perduración de las "desigualdades persistentes".

Anibal Quijano llamó la atención sobre este punto desde América Latina ${ }^{5}$. La noción de "clasificación social" es trascendental en su obra, y procura ir más allá de la teoría de las clases sociales, aunque esto no implique en absoluto -como algunos han querido interpretar- que niegue la importancia del concepto de clase. Como se aprecia en los términos escogidos por el autor, se trata de partir del proceso social que clasifica y no de su resultado, lo cual implicará revisar en detalle las formas históricas concretas de esa clasificación

5 Quijano es uno de los representantes más destacados del Grupo o Proyecto "Modernidad/Colonialidad", de esa "colectividad de argumentación", como proponen llamarla Restrepo y Rojas (2010, p. 30), retocando la denominación "comunidad de argumentación" de Escobar (2003, p. 70). Anibal Quijano, Walter Mignolo y Enrique Dussel forman "uno de los enlaces más vitales y productivos de la colectividad" (Restrepo y Rojas, 2010, p. 33). Para un relato resumido de los encuentros y publicaciones que plasmaron dicha colectividad y diseñaron su perspectiva, puede verse, además de los textos citados, Castro-Gómez y Grosfoguel (2007). 
y contemplar heterogéneas dimensiones de poder y desigualdad en su articulación específica. Cualquier proceso de clasificación social es resultado de unas determinadas relaciones de poder, del intento por imponerlas, modificarlas o reemplazarlas por otras.

El concepto de clasificación social, en esta propuesta, se refiere a los procesos de largo plazo, en los cuales las gentes disputan por el control de los ámbitos básicos de existencia social y de cuyos resultados se configura un patrón de distribución del poder centrado en relaciones de explotación/dominación/conflicto entre la población de una sociedad y en una historia determinadas (Quijano, 2000a, p. 367).

En el mismo movimiento en que propone "avanzar hacia una teoría histórica de la clasificación social” (Quijano, 2000a, p. 367), Quijano introduce la cuestión racial como una urgencia teórica y política, dando forma a una de las intervenciones de mayor impacto de la perspectiva decolonial. En varios de sus trabajos (2000a, 2000b y 1999), Quijano sostiene que la idea de "raza" tiene una historia que comienza con la conquista de América: "con la formación de América se establece una categoría mental nueva, la idea de 'raza'” (Quijano, 2014 [1993], p. 758). América y Europa se constituyen ambas en el mismo proceso, que se inicia con dicha conquista y configura un patrón específico de poder. Este patrón de poder, vigente en nuestros días en sus lineamientos centrales, se caracteriza por cuatro ejes. El primero de ellos, que tiene vital importancia aquí, consiste en

la clasificación social básica y universal de la población mundial sobre la base de la idea de "raza". Esta idea y sus efectos en las relaciones de poder son un producto de la dominación colonial. En consecuencia, dicha clasificación social tiene carácter colonial y es un elemento de colonialidad en el poder (Quijano, 2008, pp. 187-188).

El segundo eje, que nos recuerda la imbricación de "raza" con la división del trabajo, es

La formación de una estructura de control del trabajo, de sus recursos y productos, que articuló a todas las formas históricamente conocidas (esclavitud, servidumbre, pequeña producción mercantil independiente, reciprocidad y salario) en torno de y bajo el predominio de la relación capital-salario... y del mercado mundial (Quijano, 2008, p. 188).

A esta importancia de América en la configuración de la "raza", que en tanto manera y producto de la dominación colonial impregna todos los ámbitos del poder capitalista mundial, Quijano añade observaciones acerca de su actualidad. Por un lado, la colonialidad, engendrada en el colonialismo, ha mostrado ser más profunda y duradera que este, y entonces el racismo, la

$6 \quad$ El tercer eje es la división del globo entre regiones (blancos o europeos / de color; centros imperiales / regiones dependientes) en torno de Europa como la sede del control de esa estructura mundial de poder y el cuarto "el eurocentrismo como la perspectiva dominante de intersubjetividad y de conocimiento" (Quijano, 2008, p. 188). 
manifestación "más perceptible y omnipresente" de la colonialidad del poder, "no ha dejado de ser el principal campo de conflicto" (Quijano, 1999, p. 142). Por otro lado, el autor propone como hipótesis en un texto publicado originalmente en 2003 (y ofrecido antes como conferencia en 1998) que

estamos inmersos en un proceso de reclasificación social de la población del mundo, a escala global. Es decir, las gentes se distribuyen en las relaciones de poder, en una tendencia que no se restringe solamente a las relaciones capitalsalario, sino que ahora concierne más a todo lo que ocurre con el conjunto de la explotación capitalista, así como con las viejas formas de dominación social embutidas en esos constructos mentales de la modernidad que se conocen como raza y género (Quijano, 2008, p. 199)․

\section{Disputas en torno a la visibilización indígena en Argentina}

En junio de 2007 Celima Torrico pasó por una situación enojosa en el aeropuerto internacional de Ezeiza, Argentina. Torrico es boliviana, quechua, y estaba vestida con ropas indígenas (precisión que, útil para la descripción, ciertamente no debe entenderse como "explicativa" de nada). Cuando aguardaba para hacer los trámites migratorios, un funcionario la separó de la fila que correspondía a pasajeros con pasaporte diplomático. La mujer describió la escena: "Al verme en la fila de diplomáticos, el funcionario de Migración murmuró diciendo, ‘cómo esta india va a ser diplomática?', y a los gritos me dijo 'che, che, che, mamita salí de ahí, vení'” (Perfil, 2007). Por entonces, Celima Torrico era Ministra de Justicia de Bolivia y dirigente de productores de coca de la región del Chapare, y había viajado a la Argentina para participar en un evento vinculado a derechos humanos. Luego de aclarar que era una alta funcionaria pudo hacer los trámites donde le correspondía y salir de la Argentina.

La escena anterior es elocuente acerca del peso de las apariencias y del modo en que lo que vemos en los cuerpos de las personas que nos rodean afectan más o menos directamente el trato que tendremos con ellas. En este acto discriminatorio han confluido cuestiones raciales, étnicas y nacionales, muy probablemente también de género y acaso de clase. La pregunta "¿cómo esta india va a ser diplomática?" supone representaciones más o menos precisas acerca de cómo pueden ser, dónde les corresponde estar y qué les toca hacer

7 Diferentes autores, como Hall (2000) y Balibar (2004), han señalado la actualidad de la racialización, el racismo y la "raza" en el contexto europeo, otros trabajos (Harrison, 1995, Hall 2000 y 2003, Balibar 2003a y Hund 2003) se detienen en las diversas combinaciones contemporáneas de "raza" con argumentos "culturales", así como otros (Balibar y Wallerstein, 1994) lo habían hecho sobre la imbricación entre raza, nación y clase. A su vez, para una crítica de la noción de "racismo sin razas", ver Stolcke (1995). Para la relación de "raza" con "sexo" y con "género", Guillaumin (1992 y 2002) y Stolcke (1992 y 1999). Para críticas teóricas y reconstrucciones históricas de la noción de "raza", pueden consultarse Stocking Jr. (1968), Arendt (1973), Banton (1977), Malik (1996), Foucault (1996), Todorov (2000) y Balibar (2003b), y para genealogías de "raza" en América Latina, de la Cadena (2008). 
a los indios (y las indias). El caso muestra el impacto de estas percepciones discriminatorias cuando se vuelven práctica administrativa.

Los modos de percepción y valoración que intervienen en nuestra relación con los demás y le dan una primera estructuración son, desde luego, socialmente aprendidos. En ese aprendizaje tienen vital importancia los mecanismos de representación "no lingüísticos", y entre ellos las imágenes visuales se destacan por configurar cuerpos y sujetos apreciados o despreciados a los cuales atribuyen características presuntamente propias, vinculan a determinados espacios, circunstancias y acciones, marcan y clasifican. Tales imágenes enseñan a ver y reconocer, y juegan un papel fundamental en la instauración de un sentido común (Gramsci, 1985) y, en particular, de un "sentido común visual" (Caggiano, 2012).

¿Cómo se visibilizan ciertos grupos y sectores sociales en la historia?, ¿quién es quién y quién ha sido qué en los relatos construidos acerca de nuestras sociedades?, ¿quiénes han sido y quiénes no han sido parte de la nación, o no lo han sido plenamente? Más precisamente, ¿qué imágenes de "indígenas" o "pueblos originarios" en Argentina ofrecen los múltiples dispositivos que ponen a circular públicamente representaciones visuales de estos grupos? Las imágenes y los relatos que pugnan en torno de la construcción y reconstrucción de la historia ponen el foco sobre ciertas diferencias y no sobre otras, señalan a unos "diferentes", ocultan a otros y otros, por fin, no aparecen como "diferentes" porque constituyen, muchas veces implícitamente, la norma a partir de la cual las diferencias se establecen.

"El proceso argentino de construcción de la nación se basó en la idea de extinción de los indios argentinos" (Kropff, 2005, p. 109, Briones y Díaz, 2000), y la historia oficial en una variedad de estrategias de negación e invisibilización (Briones, 1998). A pesar de que desde comienzos de la década de 1980, en el marco de la creciente defensa de los derechos humanos en la región, ganó un lugar en la arena pública la defensa de los derechos de los/as indígenas, y de que durante los noventa la fuerte movilización de organizaciones locales y la actuación de agencias internacionales consiguieron una serie de reconocimientos jurídicos, está claro que las representaciones visuales hegemónicas ${ }^{8}$

$8 \quad$ Parto de distinguir aquí repertorios visuales hegemónicos y alternativos. Dado que la "hegemonía" es un proceso social dinámico y complejo (Williams, 2000), resulta muy difícil definir de antemano cuáles repertorios ocuparán "indudablemente" una u otra posición. No obstante, es posible (e inevitable, en términos metodológicos) establecer algunos puntos de partida empíricos, y lo hago aquí en relación con dos criterios: 1) el lugar de enunciación del productor de repertorios visuales, incluyendo la capacidad técnica para realizar tal producción y 2) la circulación de esos repertorios, como resultado de la potencia de difusión y/o de la receptividad social que logren. En cuanto a la calidad "alternativa" o "contrahegemónica", se agrega el criterio de la autoadscripción, es decir, el hecho de que las organizaciones, instituciones o grupos responsables de la elaboración y difusión de tales materiales se proponen a sí mismos como una mirada diferente, alternativa o contraria a las oficiales o dominantes, una perspectiva que repone ausencias, vuelve visible aquello que se ha ocultado o intenta ocultarse, discute unas determinadas representaciones y ensaya otras. En otro lado (Caggiano, 2012), la interpretación contrastiva de los repertorios permitió mostrar que las posiciones hegemónicas o alternativas son contextuales, variables y, no pocas veces, internamente contradictorias. 
continúan poniendo en acción, en sus líneas maestras, dichas estrategias de negación e invisibilización.

Las imágenes de los repertorios hegemónicos considerados aquí (un álbum de fotografías históricas y manuales escolares) ${ }^{9}$, se caracterizan por la reclusión de los indígenas y de "lo indígena" en el pasado de la Argentina y su borramiento del presente de esta sociedad. Las imágenes de la "Argentina Indígena", como se titula uno de los apartados del álbum histórico analizado, son imágenes de un pasado lejano, ninguna es posterior a finales del siglo XIX, y traen reminiscencias de vitrinas de museo (Figuras 1 y 2). Indígenas con armas y otros "items de cultura material... usados como marcadores de 'primitivismo'"' (Edwards, 1996, p. 20) se muestran incongruentes con el mundo blanco. Son las fotos de una Argentina indígena que está destinada a desaparecer (o mejor, a aparecer como desaparecida) de los relatos oficiales de la nación. La peligrosidad primitiva del guerrero, que persiste apenas como pieza de museo, recuerda la "razón" para la "guerra al indio", para su desplazamiento o su exterminio. Al mismo

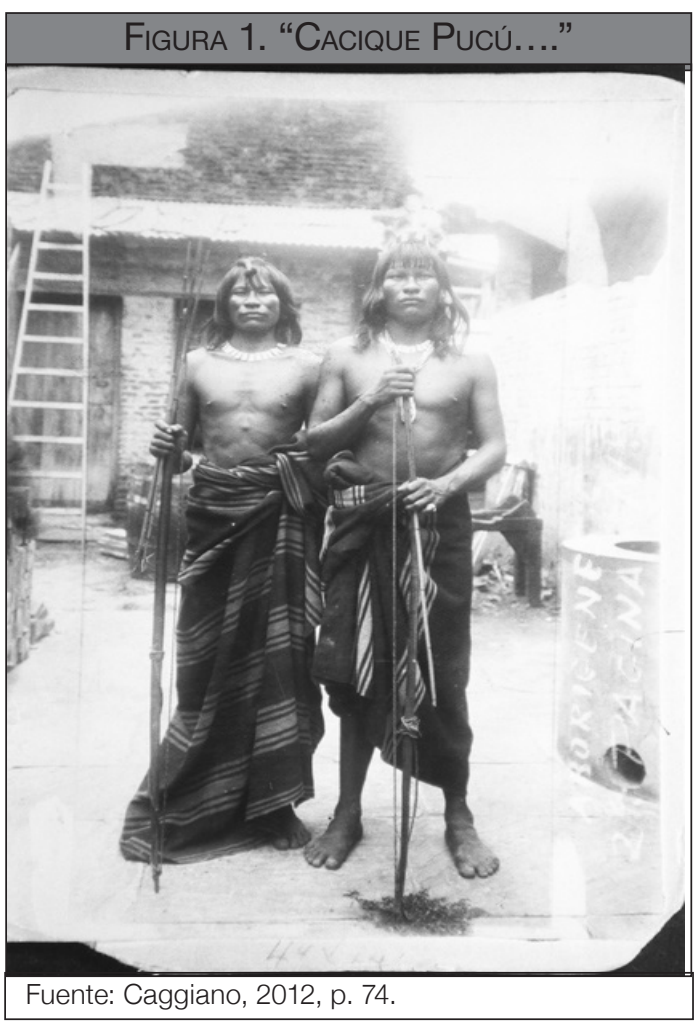
tiempo, el espíritu guerrero habría sido aquietado y "el indio" sobreviviente habría sido tarde o temprano asimilado por completo. El repertorio visual viene a confirmar cien años más tarde esta pretendida extinción, uno de los ingredientes

9 Si bien la investigación general incluyó también prensa de gran tirada, los materiales que utilizo en este artículo son imágenes de dos procedencias. Por un lado, las fotografías de los cuatro tomos del álbum La Fotografía en la Historia Argentina, entregado gratuitamente por el periódico Clarín a finales de 2005. Clarín es el periódico más influyente de Argentina, parte del holding multimedia más grande del país y de uno de los más grandes de América Latina. Editado en Buenos Aires, es por mucho el de mayor tirada y más amplia distribución en el país, además de ser la referencia privilegiada tanto por otros medios como por políticos y dirigentes de diversos sectores e instituciones en la "definición de agenda". Por otro, las imágenes visuales de tres manuales escolares de Ciencias Sociales del segundo ciclo de la Educación General Básica (EGB) de 2006, uno de la editorial Santillana, uno de Tinta Fresca y uno de Puerto de Palos, dirigidos a niños y niñas de aproximadamente nueve años de edad. Los tres han sido editados en la ciudad de Buenos Aires y se proponen atender los asuntos en una dimensión o con un enfoque nacional. Las tres editoriales escogidas son de gran tirada y, según se infiere del costo de cada libro y de la opinión de maestros y libreros especializados, apuntan a públicos diferentes de acuerdo con los niveles de ingreso. 
fundamentales de un discurso según el cual la "Argentina indígena" constituye un período acabado, un capítulo del pasado de la historia nacional.

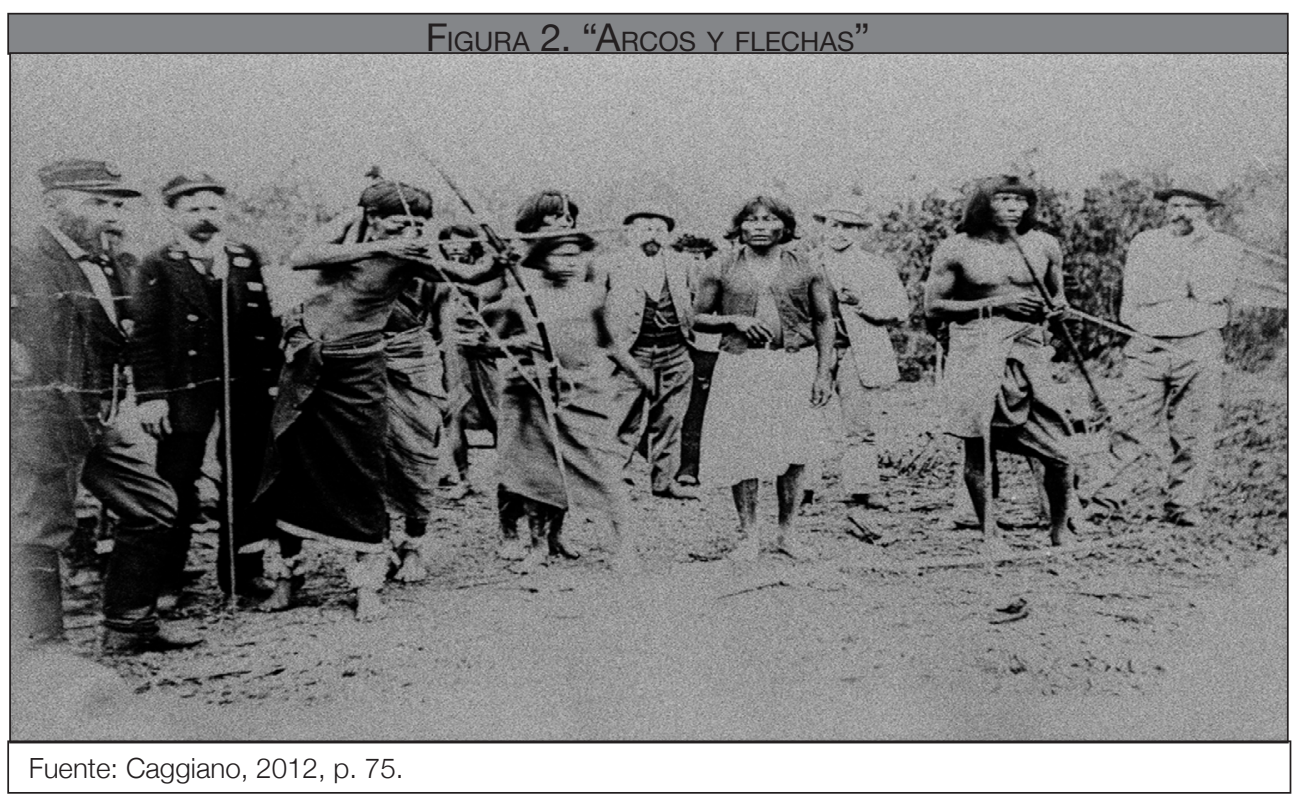

Las muy escasas imágenes actuales reponen también el pasado y reenvían a la vitrina de museo, como sucede con fotos que reiteran trazos característicos de las fotografías de "tipo" del siglo XIX, al reproducir su encuadre y su composición y apelar a los tradicionales etiquetamientos generalizantes en sus leyendas ${ }^{10}$. Nos dicen que tenemos que ver allí a un ejemplar de la raza.

La foto del "Nativo guaraní actual" (Figura 3), por ejemplo, pertenece a uno de los manuales escolares analizados. Más allá de tratarse de una imagen en color, los restantes rasgos formales recuerdan los de aquellas fotografías de "tipo": se enfoca el torso desnudo del "Nativo guaraní" en primer plano y de frente, así como su rostro que mira a la cámara; se aprecian sus rasgos físicos y pocos elementos más. El pie de foto completa la caracterización. "Por medio de la yuxtaposición de una forma y una leyenda representacionales específicos... los 'tipos' son establecidos o... un individuo consigue tornarse una generalidad. Leyendas generalizadoras como 'Un nativo típico', 'Una beldad

10 Estudios antropológicos e históricos de la fotografía (Poole, 2000; Smith, 1999 y 2004) han mostrado cómo esta tecnología visual jugó un papel clave en la producción misma del concepto moderno (biológico, científico y clasificatorio) de "raza", una de las formas históricas concretas que tomó esta categoría "resbaladiza" (Poole, 2000, p. 26). "En el campo de la ambigüedad y fluidez que la «raza" constituye, la fotografía y las tecnologías visuales del «tipo" que la precedieron jugaron un rol crucial en la producción del propio concepto de la «raza»" (Poole, 2000, p. 261). El encuadre que aislaba a la persona fotografiada del entorno, tomándola de frente, en general en un plano medio corto o en un primer plano, otorgaba dimensión física a la noción de "tipo" y ofrecía la materialidad que la mirada fisiognómica procuraba. Acerca de las fotografías de tipo racial en Argentina, ver Penhos (2005) y Caggiano (2013). 
FIGURA 3. "NATIVO GUARANÍ ACTUAL"

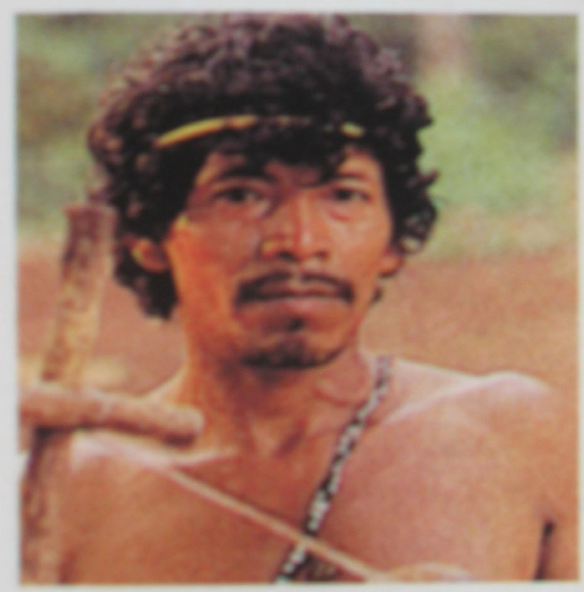

Nativo guarani actual

Fuente: Caggiano, 2012, p. 123.

nativa'... funcionan de esta forma" (Edwards, 1992, p. 11).

Pero como señalé hace un momento, esta característica de los discursos hegemónicos ha comenzado a agrietarse en las últimas décadas. Además de los cambios jurídicos de la década del noventa del siglo pasado, el Estado argentino incorporó la temática indígena en el Censo Nacional de Población de 2001, y en 2004-2005 realizó una Encuesta Complementaria de Pueblos Indígenas. "Las organizaciones indígenas ganaron visibilidad y derechos políticos generando un cuestionamiento sistemático a las prácticas de inclusión/exclusión de la sociedad política y civil" (Kropff, 2005, p. 108) y comenzaron a romper el largo proceso de silencio e invisibilización, abriendo una discusión que está en pleno desarrollo acerca de la presencia indígena, de las formas históricas de violencia política y militar de su despojo y de la negación simbólica que acompañó y sucedió a ese despojo.

Circulan, entonces, imágenes que pueden reunirse en un segundo grupo, el de los repertorios alternativos. Las analizadas provienen básicamente de sitios de Internet elaborados por organizaciones de pueblos indígenas o de periodismo independiente que trabaja con estos pueblos ${ }^{11}$.

Uno de los rasgos visuales más extendidos en estos sitios viene dado por la "simple" insistencia en la presencia actual de los/as indígenas en Argentina. Tal actualidad se hace visible de diversas maneras. Una de ellas es la recurrencia de imágenes de niños y de jóvenes, muchas veces con indumentaria o accesorios que remiten al rock, al punk o a algún otro género urbano contemporáneo (Figura 4). Otras imágenes que ponen en foco esta actualidad de los pueblos

11 Fueron consultados más de cien sitios en internet, veinte de los cuales conforman esta parte del corpus. Los sitios considerados son diversos, como son diversos los grupos realizadores o responsables de los mismos. Hay propuestas "comunitarias", que circunscriben su trabajo a un grupo en particular (mapuche, toba, etcétera), lo cual no implica que no tengan contactos con otros grupos o no realicen acciones conjuntas. Otras involucran a varios grupos indígenas, a partir de intereses $u$ objetivos comunes. Otras, por último, abordan los problemas o reivindicaciones de "los pueblos originarios" o "los indígenas" tomados en conjunto. En su mayoría, estas últimas corresponden a sitios de periodismo que se reconoce como "independiente" o "alternativo", que otorga gran importancia a la cuestión indígena, abundante cobertura y un lugar jerarquizado dentro del conjunto de notas. Las organizaciones consideradas difieren también en el tipo de relación que mantienen con los Estados y con organismos internacionales u organizaciones sociales internacionales o globales. 
originarios son aquellas que destacan las nuevas tecnologías en los contextos habituales en que miembros de estos pueblos llevan adelante sus actividades. Las computadoras portátiles están entre los motivos habituales de estas tomas (Figura 5). Se dedican también muchas imágenes a exhibir la participación política indígena, con tomas de marchas, manifestaciones y sentadas, o que registran su intervención en instituciones del régimen democrático, como la visita a una Legislatura

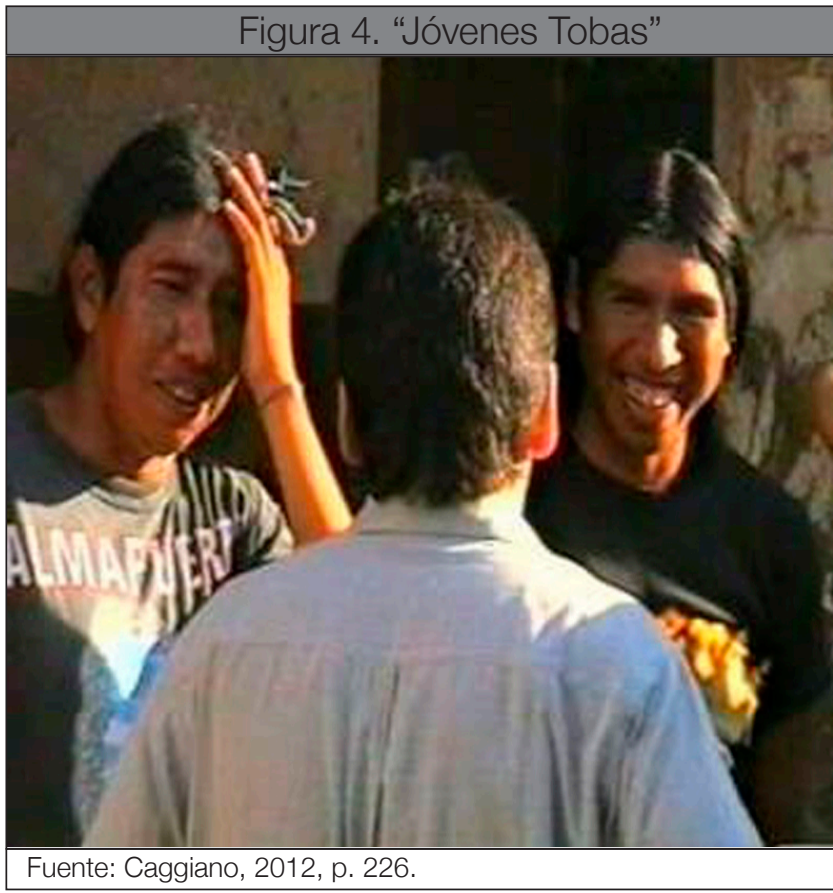
(Figura 6) ${ }^{12}$. Estas imágenes, en síntesis, insisten en la visualización de la di-

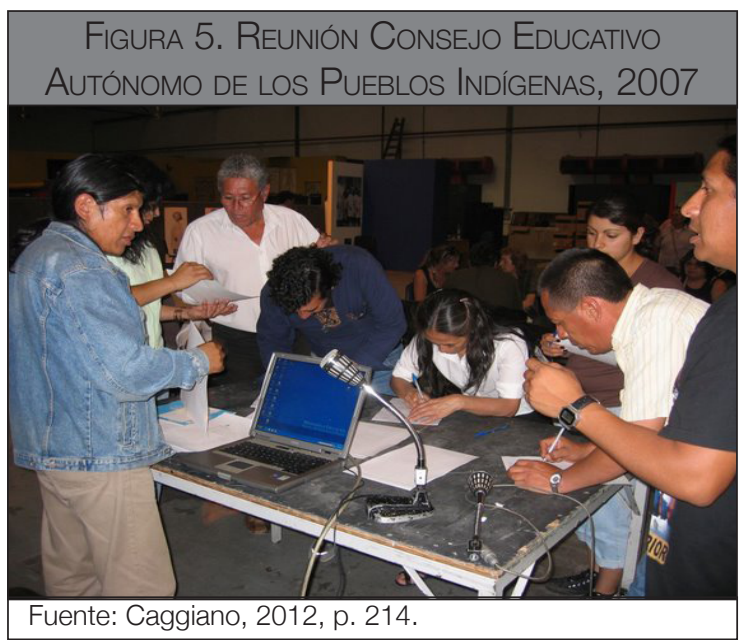
mensión política de la presencia indígena, así como de una cotidianidad que incorpora las tecnologías o las instituciones de las sociedades occidentales contemporáneas y que, por ello, se aleja de los estereotipos arcaizantes de los lugares, tareas y herramientas que serían propios del mundo indígena, según la representación hegemónica.

Roland Barthes señaló que "nunca puedo negar en la Foto-

12 Para calibrar la envergadura de este último aspecto, vale notar, como ha hecho de la Cadena, que la atribución diferencial y excluyente del pensamiento político y la acción política puede considerarse un aspecto clave de lo pensable y de lo impensable que la raza y el racismo han organizado en las sociedades latinoamericanas desde la Colonia. La capacidad de reflexión y acción políticas sería un atributo reconocido a determinados actores y negado a otros. Mirado desde los sectores hegemónicos, "Ios indios" no harían política. Pueden provocar desórdenes y presionar, pueden ser controlados y también llevados de las narices por otros actores políticos, pero no harían ni pensarían la política per se (de la Cadena, 2008). En este sentido, la inscripción visual de los indígenas en el mundo de la política implica el desafío de conmover el imaginario hegemónico en uno de sus rasgos estructurantes. Estas imágenes politizan la presencia indígena al tiempo que indigenizan el campo político. 


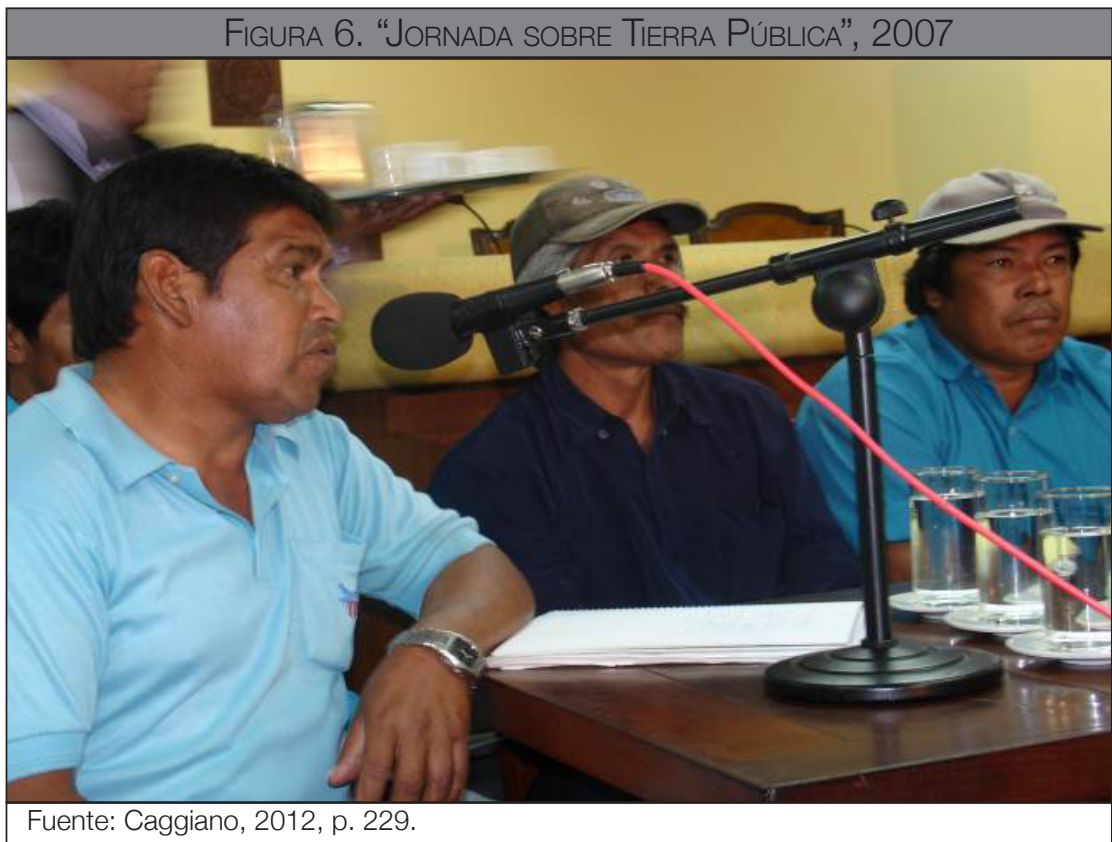

grafía que la cosa haya estado allí. Hay una doble posición conjunta: de realidad y de pasado" (Barthes, 2005, p. 121). En otro pasaje menos comúnmente citado, Barthes también sostiene que "la Fotografía no dice (forzosamente) lo que ya no es, sino tan solo y sin duda alguna lo que ha sido" (Barthes, 2005, p. 132). Las fotografías de los repertorios alternativos muestran precisamente lo que ha sido y lo que aún es, lo que sigue siendo, lo que insiste o resiste, para usar un término que suelen emplear los redactores de estos sitios de Internet, como si la utilización de estas fotos desafiara esa relación definitoria de la toma fotográfica con el pasado y buscara la restitución de una vitalidad. El contraste con las imágenes de los repertorios hegemónicos permite ver en qué sentido en los sitios indígenas el "esto ha sido" deja también lugar al "esto es", el pasado al presente y la muerte a la vida. Podría decirse que la visualización de lo indígena actual en Argentina es en sí misma una visualización alternativa.

Tenemos así, de un lado, las fotos de finales del siglo XIX y primeros años del XX, y las fotos actuales que reproducen el modelo de las fotos clásicas de "tipos" raciales o étnicos, como los principales mecanismos para fijar lo indígena en un tiempo remoto, así como para ofrecer la clave interpretativa racial (acorde al racialismo científico clasificatorio de aquellos años) con la cual percibir a estos grupos. De otro lado, el presente y el futuro en las imágenes de niño/as y jóvenes, en la modernidad de las nuevas tecnologías como parte de la cotidianeidad indígena y en la politicidad de ese presente y ese futuro. Estamos, entonces, ante una clara divergencia en la construcción y adjudicación de referencias temporales y criterios de visibilidad para los pueblos indígenas. 
De hecho, estamos ante una suerte de hiato que se abre en la mostración de la historia de las imágenes indígenas y de los/as indígenas en la historia de las imágenes. Entre la reclusión en el pasado y la reivindicación de la presencia actual se tiende un manto de invisibilidad que es él mismo invisible. Y no es que no existan imágenes que correspondan a las largas décadas de ese hiato o que no estén disponibles. En efecto, en archivos públicos que son de acceso relativamente sencillo y presentan pocas limitaciones para su aprovechamiento, como el Archivo General de la Nación (AGN) ${ }^{13}$, es posible encontrar imágenes que no pertenecen al pasado remoto ni al presente inmediato, sino a esas décadas intermedias, y que no parecen estructuradas en torno a los criterios de ninguno de los dos conjuntos de fotografías analizados. Es ciertamente la existencia de estas imágenes en archivos públicos lo que vuelve inquietante el hiato entre la mostración de aquel pasado y la de este presente.

\section{Incomodidades con los indígenas "a la moderna"}

La anotación en el reverso de una fotografía de comienzos de 1920 permite caracterizar estas imágenes: "Indios tobas en la Pcia. de Jujuy. Cacique trajeado a la moderna". La elección del coleccionista o del archivero que rotuló la foto es significativa. Tal vez "solo" quiso decir que se trataba de ropa contemporánea al momento en que la foto fue tomada, que puede coincidir o no con el momento en que fue incluida en el acervo, pero en la expresión "trajeado a la moderna" el término "modernidad" parece cargar con su peso filosófico, estético y político e implicar "a la occidental".

Son numerosas las fotografías en el archivo de indígenas, particularmente varones, llevando ropas modernas y/u occidentales. Estos hombres están vestidos no solo modernamente sino de manera urbana, con prendas y accesorios de ciudad, aunque algunos llevan prendas rurales que se combinan con las urbanas. Acaso la idea misma de estar alguien "trajeado a la moderna" presuponga componentes urbanos del atuendo. La modernidad de estos indígenas trasunta, asimismo, en ciertos aspectos de la composición de la toma, particularmente en la postura de los cuerpos retratados. No son fotos de "tipo" étnico o racial, cuerpos rígidos, de frente o de frente y perfil ante la cámara, despojados (pretendidamente) de subjetividad, ejemplar de su grupo. En un caso, las manos en los bolsillos del fotografiado, por ejemplo, distienden el cuerpo, en otro, la disposición de los torsos y de las miradas ponen el foco en la conversación y el intercambio, o bien la atención

13 El Departamento de Documentos Fotográficos del Archivo General de la Nación contiene uno de los acervos más importantes del país y constituye la principal fuente para quienes utilizan imágenes históricas en su trabajo de producción cultural, entre ellos las empresas y organizaciones sociales consideradas en este artículo. Las relativas limitaciones de acceso al acervo son, básicamente, los costos de manipulación y reproducción -que, en rigor, son bajos- y la localización del archivo en la ciudad de Buenos Aires. Fuera de ello, se trata de una institución abierta y el trabajo con sus documentos no presenta obstáculos formales. 
de la cámara está en el hecho de tomar la palabra, en el gesto de las manos y en la mirada del retratado a su interlocutor fuera de cuadro (Figura 7). En la figura 8 , a su vez, no es solamente el traje y la corbata lo que puede llamar nuestra atención. La postura del cuerpo, en pose seguramente solicitada por un fotógrafo profesional (la mano del fondo sostenida posiblemente sobre una mesa, el cuerpo y el rostro vueltos hacia la cámara), contrasta claramente con el rótulo, este sí propio de las fotos de "tipo": "Indio toba".

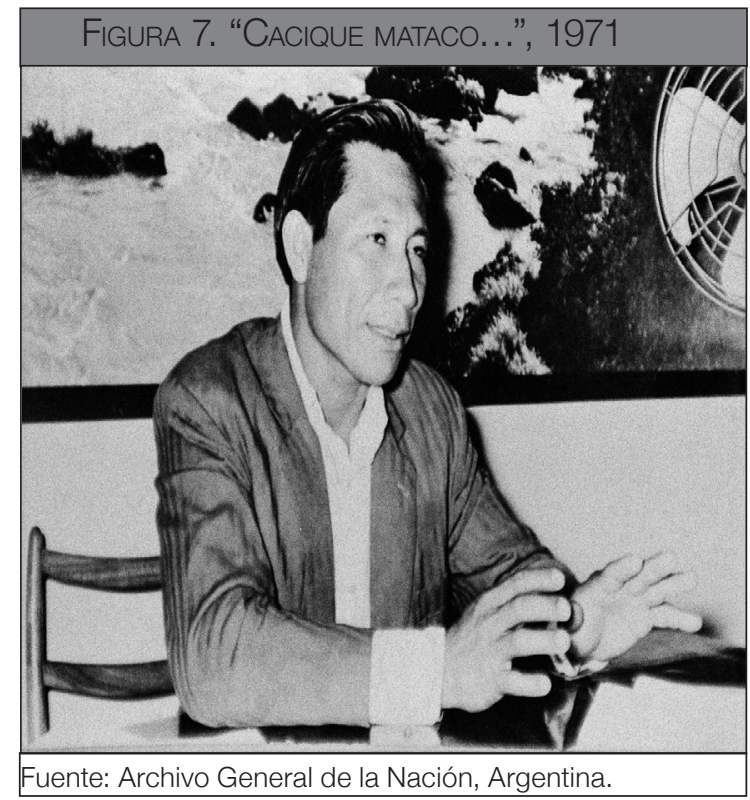

La existencia de estas fotos en el Archivo General de la Nación llama la atención sobre su inexistencia en los álbumes, manuales escolares y sitios de Internet. Las fotos de indígenas "trajeados a la moderna" quedan en los sobres y los sobres en las cajas del Archivo; no pasan el proceso de selección para salir de allí y formar parte de repertorios de gran circulación. El hiato entre las imágenes con cien años de antigüedad y las actuales da lugar a un vacío que sorprende justamente

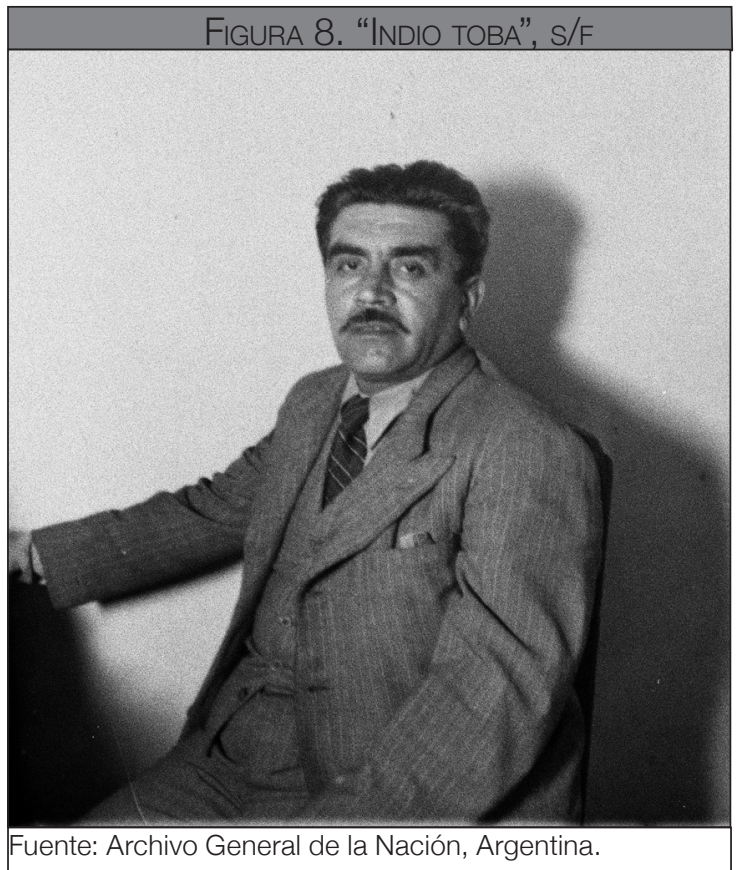
por la abundante existencia de fotos de ese período en acervos públicos como el del AGN. El hiato y el vacío seguramente tienen motivos diversos, entre los cuales las fotos de los "trajeados a la moderna" permiten destacar un aspecto relevante.

La indumentaria y las posturas modernas no son adecuadas para mostrar indígenas en los repertorios hegemónicos, como sí lo es una desnudez controlada y pretérita. Esas imágenes que recorren todo el siglo XX no contienen testimonios de primitivismo ni otros elementos que puedan servir al relato de la desaparición histórica. Para el 
punto de vista que confeccionan los repertorios hegemónicos, la modernidad de las ropas y las posturas desindigeniza a "los indios". Complementariamente, la exhibición de fotos de indígenas "a la moderna" indigenizaría la imagen de la Argentina del siglo XX, de su historia reciente, porque tales imágenes vendrían a mostrar, a contramano de lo que el tradicional discurso de la negación de la presencia indígena aún sostiene, que muchos señores de traje y corbata presentes en tantos espacios y momentos de esta sociedad son indios. Es ante este doble riesgo, que es uno solo, que esas imágenes no pasan el proceso de selección hegemónica que las trae del acervo a la circulación pública.

En los sitios alternativos o contrahegemónicos, a su vez, ocupa un lugar relevante la táctica de "destipificación" de fotografías, y en esta táctica juegan un papel importante no únicamente las imágenes políticas y aquellas con marcadores de modernidad, sino otras con abundancia de símbolos, como el kultrun, el gemil o la wiphala, y de objetos de la "naturaleza", como paisajes, porciones de tierra, vegetación y animales (Caggiano, 2012). Esto puede interpretarse como una búsqueda de visualización de lo indígena sin visualización de "tipos raciales", una visualización de lo indígena que evita enfocar fenotipos y, así, consagrar unos cuerpos y unos rostros a la vitrina del museo.

Ahora bien, las fotografías de los "trajeados a la moderna" podrían complicar el desempeño de esta táctica. Al no contar con estos elementos -símbolos, banderas, paisajes-, podrían llevar a ver la pertenencia étnica o racial precisamente en los rasgos físicos, el color de piel o la forma del cabello (en virtud del adiestramiento histórico de dispositivos hegemónicos que enseñan a ver algo de lo social en ese tipo de rasgos). Allí hay unos señores cuyas actitudes corporales y vestimentas no se ven marcadas étnica o racialmente. $\mathrm{Ni}$ los trajes, ni las posturas, ni entornos como el de una oficina ayudan a mostrar esta parte de la historia y sus personajes como "indígenas" u "originarios". Lo indígena de las fotos podría recaer, entonces, sobre el cuerpo mismo de los retratados y esto conllevar los riesgos de una suerte de retorno de la fisiognomía. Así las cosas, esta "modernidad" indígena supone un problema también para las organizaciones indígenas e indigenistas.

En resumen, en los repertorios hegemónicos aquellas fotos no sirven para mostrar una Argentina indígena racializada del pasado; utilizarlas implicaría mostrar la presencia indígena de traje y con anteojos, en ciudades y oficinas, o sea, indigenizar la historia moderna del país. En los alternativos, razones muy distintas (opuestas, en cierto modo) hacen igualmente que aquellas fotos no sean recuperadas; utilizarlas podría reponer el señalamiento "tipificador" de unos cuerpos y unos rostros como indígenas, y esto podría evocar modos hegemónicamente racializados de mirar. 


\section{Los intrincados caminos de la raza y los riesgos de la deriva decolonial esencialista}

Es necesario volver conceptualmente sobre la idea de "raza", los procesos de racialización y de clasificación social para comenzar a desbrozar un panorama que se ha vuelto enmarañado en torno a lo que de la Cadena sintetizó como "la fascinante vacuidad de la raza" (de la Cadena, 2008, p. 13). Recurriendo a genealogías particulares de la "raza" en América Latina, la autora observa que este carácter "vacío", lejos de restarle fuerza o historia, se las da, en el sentido de que su inestabilidad y mutabilidad le ha permitido a la "raza" enraizarse en esas genealogías diferentes, adquirir potencialidades diversas y articulaciones múltiples. Su especificación no conduce al relativismo, del tipo "cada quien (o cada sociedad) tiene su noción de raza singular", lo cual constituiría una resolución falaz del problema. "Las definiciones de raza son dialógicas", apunta de la Cadena, y tales diálogos "están articulados por relaciones de poder. La raza responde a geo-políticas conceptuales locales, nacionales e internacionales" (de la Cadena, 2008, p. 13).

Al ir al mundo colonial en su reconstrucción histórica, la autora refiere la sorpresa de religiosos y funcionarios españoles ante la facilidad con que podía blanquearse un indio o ante las dificultades para distinguir un mestizo de un español. Esto le permite señalar que el color no dependía, en ese contexto, solo de la piel, sino también de la reputación. La "incertidumbre fenotípica" aparece así como un rasgo fundamental. En la historia de la raza en América Latina, continúa de la Cadena, se irá dando la imposición del criterio filosófico y europeo que asocia la raza al color de la piel, pero siguen "vigentes e incoherentemente desafiantes" (de la Cadena, 2008, p. 23) los hábitos locales que enfatizan la calidad y la reputación para definirla. "De esta genealogía resulta una de las características idiosincrásicas de las clasificaciones raciales en América Latina: la relatividad de los rasgos somáticos en la definición de las personas" (de la Cadena, 2008, p. 23).

En Argentina, en la medida en que el proyecto de homogeneización cultural que fue correlato de la construcción del Estado nación moderno entre 1880 y 1930 tuvo éxito (Segato, 1997; Guber, 1997), las dimensiones racial y étnica perdieron la fuerza que habían tenido en el pasado como criterios de clasificación social. Dicho proyecto logró producir un silenciamiento de las dimensiones racial y étnica que, al tiempo que las sustraía del campo de lo politizable, las volvía operativas en su capacidad de negar a los otros ${ }^{14}$. En este contexto, la "raza" y el racismo se instalaron en Argentina "por debajo de la esfera de la normatividad" (Briones, 1997) y, en consecuencia, no se habla

14 "En Argentina no hay negros" o "en Argentina no hay indios" son fórmulas míticas que es habitual oír todavía hoy. Estas fórmulas están lejos de volver inexistentes a "los negros" y a "los indios", lo que hacen es volverlos una existencia negada. 
el lenguaje político de la "raza". Frigerio, por su parte, sostiene que "en nuestro país es la raza el factor que permanece ocluido, y poco enunciable... Sin embargo en nuestras interacciones... el color de la piel y otros rasgos fenotípicos -y las inferencias que realizamos en base a éstos- resultan importantes" (Frigerio, 2006, p. 94).

En este marco, los repertorios visuales, menos normativos aunque no menos normalizados que los discursos verbales institucionales, pueden activar con relativa sencillez, a diferencia de estos, la "raza" y el racismo. En ellos es posible apreciar el funcionamiento de estas dimensiones y posiciones ocluidas, silenciosas pero visibles. Echando mano de modos de ver y mostrar que tienen más de cien años, pero se muestran activos en su permanencia o en su restauración, los repertorios hegemónicos reponen una determinada perspectiva racial. No es difícil entender por qué en estos conjuntos de imágenes las fotografías de los indígenas "a la moderna" no encuentran lugar.

Las dificultades de los repertorios alternativos con estas imágenes, a su vez, parecen dar cuenta de una incomodidad semejante al "escozor" que sienten muchos intelectuales a lo largo y ancho de América Latina con "raza" (Arias y Restrepo, 2010) que, si bien se ha atenuado en los últimos años, perdura intenso en contextos como el argentino. A estas dificultades se agrega el hecho de que la mayoría de las organizaciones y agrupaciones responsables de estas imágenes se encuentran compelidas, en tanto que pueblos originarios o indígenas, a establecer alguna forma de continuidad en la historia con aquellos indígenas del pasado lejano. De qué modo trabajar sobre el hiato, qué imágenes mostrar y cómo intervenir visualmente para desestabilizar imaginarios coloniales racializados es una pregunta que sigue en pie.

Las reflexiones en torno a "raza" elaboradas por autores de la perspectiva decolonial ofrecen argumentos $y$, de hecho, algunas de estas organizaciones apelan a este lenguaje, a la denuncia de la colonialidad del poder, del ser y del saber, al rastreo de experiencias que tejieron tramas de apartamiento o de resistencia a las lógicas del capitalismo moderno/colonial. Es precisamente en este punto donde creo pertinente ofrecer una consideración crítica acerca de lo que denomino la deriva decolonial esencialista.

\section{La deriva esencialista de la crítica decolonial}

Restrepo y Rojas han relevado críticas a pensadores del grupo modernidad / colonialidad, algunas que aciertan sobre limitaciones conceptuales e inconsistencias y otras que emanan de tergiversaciones de sus postulados (Restrepo y Rojas, 2010). Más allá de estas objeciones, con sus aciertos y desaciertos, me interesa reparar críticamente aquí en la expansión y difusión "horizontal" de sus ideas, en los usos y apropiaciones que investigadores e intelectuales formados hacen de ellas, ayudando a convalidar la "incidencia notoria" (Restrepo y Rojas, 2010, p. 13) de sus argumentos. Tal incidencia se da dentro y fuera de la academia en numerosos países de la región, donde 
las palabras clave de la "colectividad de argumentación" designan de manera creciente en los últimos años seminarios y cursos universitarios, dosieres en revistas especializadas, simposios y mesas en congresos, etcétera, pasando a formar parte en algunos de ellos del "sentido común" académico (Restrepo y Rojas, 2010, p. 34).

Me concentraré puntualmente en un artículo publicado en 2010 por Rita Segato, titulado "Los cauces profundos de la raza latinoamericana: una relectura del mestizaje", que resulta un buen ejemplo de esta deriva. Me detendré solo en él para poder atender su argumento con relativo detalle en el reducido espacio con el que cuento para ello. El texto está dedicado a Aníbal Quijano y aborda, como anuncia el título, el tema de la "raza" en América Latina.

La autora defiende allí la "necesidad de hablar de raza" (Segato, 2010, p. 16), de desandar "el silencio que pesa sobre la raza", y la define en el inicio del texto "como marca de una historia de dominación colonial que continúa hasta nuestros días" (Segato, 2010, p. 18). En este propósito general, tanto como en esa primera definición genérica, retoma claramente los aportes de Quijano y del proyecto modernidad / colonialidad. En el mismo sentido realiza, además, observaciones sagaces acerca de cómo el silenciamiento histórico de la raza en la región ha provocado que esta actúe acaso con mayor eficacia que si hubiera sido enunciada y formal o institucionalmente asumida.

Solo cuando la legislación que regulaba las relaciones esclavistas es abolida -advierte Segato- la raza pasa a independizarse y se vuelve canon invisible e, inclusive, innombrable... Es entonces que la racialización alcanza la plenitud de su autonomía como estructura que da forma a la realidad de las relaciones sociales y económicas, como un guión que organiza las escenas desde detrás de las bambalinas (Segato, 2010, p. 33).

Para el caso particular de Argentina, Segato alude, de manera similar a autores ya citados en estas páginas, a "una dificultad en la formulación verbal de la caracterización racial” (Segato, 2010, pp. 24-25).

Refiriéndose al "color de las cárceles" en América Latina, el artículo indica que "el dato estrictamente racial es impreciso" porque los gobiernos e instituciones no tienen datos censales que consideren "el parámetro «raza»" (Segato, 2010, p. 18). Son estos silencios los que permiten a la autora afirmar inmediatamente que "al continente le cuesta hablar del color de la piel y de los trazos físicos de sus mayorías" (Segato, 2010, p. 18, cursivas en el original). Avanzando estos pocos pasos en su argumentación, encontramos que Segato superpone a la idea de la "raza" como "marca de una historia de dominación colonial", la de la "raza" como "color de piel" y "trazos físicos", que se ofrecen como equivalentes del "dato estrictamente racial" o del "parámetro 'raza'”. ¿Qué significado y qué implicaciones tienen estos dos componentes de la "raza"? Veremos que, en conexión con cada uno de ellos, comparecen dos elementos sumamente problemáticos en el argumento de Segato. El primero, acerca de quiénes compartiríamos esa presunta "raza latinoamericana". El segundo, acerca de la 
forma en que se concibe la historia que la define. Si bien presente en ambos puntos, es en este último donde se aloja el mayor riesgo esencialista.

1) "Percibir la raza del continente" (y no "la raza en el continente", que supondría una búsqueda muy diferente) va de la mano de "la necesidad de desenmascarar la persistencia de la colonia" (Segato, 2010, p. 20). Por lo demás, el título del artículo, "Los cauces profundos de la raza latinoamericana" [cursivas añadidas], sugiere ya la existencia de una "raza" común en la región. El planteo es complejo y, por momentos, confuso, por eso recurro a una cita algo extensa:

Porque no se trata del indio en sus aldeas, ni del negro en los territorios de palenques que persisten, sino del rasgo generalizado en nuestras poblaciones y, en algunas situaciones, de nosotros mismos, ya que, como he repetido muchas veces, cuando pisamos en las sedes imperiales, ese trazo nos alcanza a todos, aunque tengamos cuatro abuelos europeos... Es el trazo de nuestra historia que aflora y aparece como un vínculo, como un linaje históricamente constituido escrito en la piel, una oscuridad que se adensa más en algunos paisajes, como las villas, favelas, cantegriles y cayampas de los márgenes urbanos, y, característicamente, el paisaje carcelario. Y que, también, precisamente porque la historia colonial no se ha, en momento alguno, detenido, es un trazo que nos tiñe a todos: los habitantes de estos paisajes somos todos no-blancos cuando viajamos al Norte imperial (Segato, 2010, pp. 18-19).

Por un lado, pareciera evidente en algunos pasajes que no se trata del cuerpo, sustantivamente entendido, sino de algo que es puesto en el cuerpo, y que tiene todo que ver con quien lo pone (con el que mira, interpreta, valora y eventualmente clasifica). Esto, como Quijano entre otros, ayudara a entender, nos saca del plano del "color de piel" y los "trazos físicos", entendidos como materia con un significado intrínseco. Es contextualmente que un "trazo físico" cualquiera se interpreta de cierta manera. Sin embargo, otros pasajes de Segato hacen volver las dudas, porque nos dice, por ejemplo, que esos son trazos de oscuridad que se adensan en algunos paisajes sociales como las villas o las favelas, entre otros. Algunos párrafos más adelante, la autora es más precisa acerca de quiénes conforman esta "raza", al enumerar integrantes de la "multitud argentina": "ese interiorano general que maneja los taxis, limpia las calles, es «cana» [policía], suboficial del ejército, changuea en los mercados, es peón de estancia, es casero, a veces encargado, ciertamente mozo de bar y restaurante, empleada doméstica en nuestras casas" (Segato, 2010, p. 25).

Si aceptamos que el valor racial del "trazo físico" es contextual, ¿qué significa que "los habitantes de estos paisajes somos todos no-blancos cuando viajamos al Norte imperial" o que "cuando pisamos en las sedes imperiales ese trazo nos alcanza a todos"? ¿Opera de la misma manera ese tal "trazo" en el caso del o la intelectual que viaja al "Norte imperial" que en el de su empleada doméstica, el del "cana" o el del peón? Es obvio que no. Y es obvio que estamos así ante el conocido riesgo de opacar las desigualdades en el 
interior de un espacio social (vgr. América Latina, una determinada nación o una región dentro de ella) por señalar enfática -y acaso exclusivamente- una frontera simbólica de exterioridad de ese espacio. Si es cierto que aun a quienes tenemos cuatro abuelos europeos pueden interpelarnos como no-blancos en los centros imperiales, es absolutamente falso que esto pueda equiparse a las formas de racialización que puede haber experimentado la empleada que quedó limpiando nuestra casa. Se trata de una vieja y trillada discusión.

2) El segundo elemento problemático en el argumento de Segato resulta más relevante porque se encuentra velado y, consecuentemente, entraña un mayor riesgo de esencialismo. Puede introducirse volviendo una vez más al título del artículo, pero resaltando ahora el fragmento restante: "Los cauces profundos de la raza latinoamericana" [cursivas añadidas]. Lo que anuncia esta parte del título es que "percibir la raza del continente" implicaría descubrir una historia subterránea que resurgiría más o menos intocada, "hallar en el rostro mestizo, no-blanco, indicios de la persistencia y la posibilidad de una reatadura con un pasado latente, subliminar y pulsante, que se intentó cancelar" (Segato, 2010, p. 20). No sabemos a lo largo de las páginas en qué consiste aquello que podría retornar, qué del pasado regresaría y cómo. No hay un solo ejemplo de la posibilidad o la actualidad de esos retornos que nos ayude a comprender la idea. Sí sabemos que se trata de una memoria que habría permanecido oculta, sepultada por efecto del poder colonial y luego del poder estatal. El mestizaje se impuso en América Latina como "cancelamiento de la memoria de lo no-blanco", estableciéndose "una clandestinidad de siglos a los cauces subterráneos de sangre originaria, a los Ríos Profundos de la memoria que a ellos se vincula" (Segato, 2010, p. 26, mayúsculas en el original). Con evocaciones a la perspectiva decolonial, el artículo alude a modos de ser y de saber que se habrían suprimido y que ahora podrían regresar si conseguimos "guiarnos... a la recuperación de viejos saberes, de soluciones olvidadas" (Segato, 2010, p. 20). Hondas vertientes sofocadas en el tiempo emergerían ahora para traernos formas de saber y de conocer abolidas que sí serían las "nuestras".

Las afirmaciones anteriores, así reunidas, resultan muy claras, y no requieren mayores comentarios si interpretamos como licencia literaria o ardor político y, en consecuencia, dispensamos de crítica las afirmaciones acerca de "cauces subterráneos de sangre originaria" y constructos semejantes.

La veladura de estos argumentos, que en cambio merece todavía cierto detenimiento, consiste en la insistencia en la historia de esta "raza". Es que la apelación a la historia puede remitir al lector a la idea de construcción y de variación social, de condiciones concretas de emergencia, de procesos en tensión en el que las personas configuran esas memorias y saberes.

Pero no es ese el carácter "histórico" de la raza en el artículo de Segato. "Historia" de la "raza" en este artículo significa, antes bien, "origen"; la historia es pasado y autenticidad que pueden recuperarse tras años de engaño y 
censura. Esto queda claro, por ejemplo, en un fragmento en que se compara sugestivamente a la historia con un "paisaje":

Esa historia, que es casi lo mismo que hablar del paisaje del cual (el sujeto) es oriundo. Su lugar en el tiempo, su situación en el mundo, la geografía que le es propia. De eso, de las marcas de origen inscriptas en el cuerpo del sujeto a partir de eventos ocurridos en su espacio-tiempo, habla la lectura racial" [cursivas añadidas] (Segato, 2010, p. 27).

Segato asegura seguir a Quijano cuando explica que su noción de "raza" no es biológica ni se cierra sobre aspectos culturales, lo cual evitaría argucias sustancialistas habituales y ya muy criticadas en las Ciencias Sociales en las últimas décadas, y afirma que la "raza", como fenómeno cognitivo o "puramente 'mental'... constituye una pista en dirección a quién se fue, y a quién, por lo tanto, se es" (Segato, 2010, p. 31). Pero la conjunción elegida por Segato -"por lo tanto" - nos lleva en una dirección diferente al peso y carácter de la historia en Quijano, al cargarla de "continuidad". El pasado en el que "uno fue" no es aquí una postulación retrospectiva, como enseñaran los estudios culturales, los poscoloniales, los de memoria o el psicoanálisis. No es tampoco el pasado sedimentado que pone límites y presiones (Williams, 2000) a lo que uno puede ser en la actualidad. Para Segato el pasado es una suerte de raíz que se proyecta, un origen que indica la dirección a tomar. Por eso la tarea que se impone es seguir la pista de quién se fue para saber quién se es. (No falta casi nada para decir "quien se debe ser" y, mediante una cabriola teórica, reintroducir sorpresivamente una forma de "falsa conciencia": aquella que no supiera interpretar correctamente la "marca de origen" del pasado).

La "raza" de Segato, que es declarada "no biológica" (Segato, 2010, p. 21) y que busca eludir los encierros del culturalismo, acaba reconduciéndonos a un viejo giro esencialista, consistente en la reificación de un origen. La "raza" en América, que comenzara siendo -en sintonía con Quijano- un patrón de clasificación social, inaugurado en un reordenamiento histórico del poder mundial, termina siendo un origen que es preciso recobrar para ser quienes somos, para recuperar el "proyecto o vector histórico" de "nuestro pueblo" (Segato, 2010, p. 38), para que por fin puedan desocultarse "los pueblos ocultos por siglos en el Nuevo Mundo, que casi perdieron los hilos de la trama de su historia" (Segato, 2010, p. 21). La historia, así, es una trama cuyos hilos pueden perderse, y es preciso recuperarlos si no queremos vivir una historia que, al parecer, ya no sería la nuestra. (Estamos nuevamente en la zona en que podemos perder también la verdadera conciencia).

Para criticar la concepción de sociedades, naciones o culturas como "objetos internamente homogéneos y externamente diferenciados y limitados" (Wolf, 2000, p. 19), Eric Wolf recurrió a la inspiradora metáfora del mundo como "una gran mesa de pool en la cual las entidades giran una alrededor de la otra como si fueran bolas de billar duras y redondas" (Wolf, 2000, p. 19). Las "historias" de Segato reiteran los puntos problemáticos que Wolf criticara. 
Dicho resumidamente, cada una de esas "historias", como proyección de un origen, sería una de estas bolas de billar en movimiento. Podemos pensar que algunas se moverían mucho y otras poco, algunas hacia adelante y otras en círculos, que algunas se sostendrían sobre el plano de la mesa y otras saltarían fuera, o podemos imaginar sucesivos juegos a lo largo del tiempo, en esa mesa y con esas bolas. Pero las bolas seguirían igual de duras y redondas, y sus colores seguirían volviéndolas igual de distinguibles entre sí.

\section{Breve coda abierta sobre las imágenes del hiato}

Volviendo a las imágenes de los repertorios analizados, y a la inquietud que trajo el hiato y la existencia de fotografías en el Archivo, la deriva decolonial esencialista resolvería con cierta facilidad el problema. En las fotografías de finales del siglo XIX indicaría ver, desde luego, indígenas dominados, literal o metafóricamente aprisionados, en las de finales del siglo XX y comienzos del $X X I$, indígenas que comienzan a ver los frutos de su lucha, levantan la cabeza y no solo aprovechan una coyuntura política para ganar (tal vez "recuperar") un lugar en la sociedad, sino que someten la modernidad de las nuevas tecnologías y de las instituciones de los Estados nación a sus saberes tradicionales y a sus necesidades e intereses primigenios. ¿Qué vería esta deriva en las (ya no) problemáticas imágenes de los indígenas modernos del siglo XX? Simplemente indígenas travestidos, con una civilización ajena incorporada, es decir, hecha cuerpo mediante indumentarias y afeites, eventualmente conscientes, en lo profundo de su ser indígena, de la falsedad de estos atuendos artificiosos, o bien llevándolos sin darse cuenta, inocentes en su falsa conciencia.

Por cierto, tratar así el problema no sería resolverlo, sino ignorarlo. Y no es que quien mire según ciertas pautas de la cultura visual local no sepa ver indígenas en las imágenes de esos hombres con trajes urbanos modernos. La dificultad es la inversa: no es que alguna cosa no se vea en estas fotos, sino que se ven muchas cosas juntas. El desafío que el hiato plantea al analista (y a las organizaciones indígenas que no han recuperado las imágenes de los trajeados a la moderna) no es cómo mostrar lo que no se muestra y no se dice, sino precisamente lo contrario: lo que estamos demasiado entrenados a ver y escuchar. Sin el anclaje del reverso de la foto, en la imagen del "cacique mataco" de la figura 7 podríamos ver a un dirigente sindical de algún gremio obrero, por ejemplo. Lo importante es que podría suceder esto sin que por ello dejáramos de ver en él a "un indio". En otros términos, es probable que un espectador vea en él conjuntamente ciertos rasgos de clase, étnico-raciales, regionales y políticos. Al mostrar mucho junto, las imágenes, menos "discretas" que las palabras (Caggiano, 2012), tienen la virtud de recordarnos que los sistemas clasificatorios funcionan juntos y superponiéndose.

El proceso de exclusión, inclusión, negación, reivindicación, blanqueamiento, etnicización, invisibilización y visibilización es un intrincado juego de 
enfrentamientos y alianzas con diversos participantes a lo largo de la historia. Si siempre hubo indígenas en la Argentina, no siempre los hubo de la misma manera, porque ese intrincado proceso implica clasificaciones, nominaciones y categorías que condicionan los modos cómo experimentamos quién es quién y qué es cada quién. "Indios", "morochos de tierra adentro", "chinos" y "chinas", "negros" y "negras", "cabecitas negras", "aborígenes", "originarios", "indígenas" son, entre otras, categorías que apelan a sistemas clasificatorios diferentes, a veces en conexión y a veces no. ¿Nombran a las mismas personas y sectores sociales a lo largo del tiempo?, ¿al clasificarlos de maneras diferentes, son las mismas personas y sectores los clasificados?

Con mucho cuidado, el problema, por demás complejo, podría ponerse también en estos términos: entre los indígenas negados y recluidos en el pasado y los reivindicados en las últimas décadas, hubo indígenas... pero muchas veces fueron otras cosas, además de (y, en ocasiones, en vez de) ser indígenas. Los procesos de inclusión, tanto como los de exclusión, los desprecios y los reconocimientos, la estructuración de asimetrías y las luchas contra ellas se dieron interpelando no a "indígenas" sino a "trabajadores", por ejemplo, que podían o no "ser" indígenas. La racialización no necesariamente utiliza un lenguaje racial, aunque evidentemente puede hacerlo, y la opresión de clase puede muy bien utilizarlo, aunque es claro que muchas veces su lenguaje no tiene que ver con "raza". Las mismas gentes, por lo demás, en distintos momentos de sus vidas o en diferentes contextos relacionales viven de acuerdo con distintas categorías y sistemas de clasificación.

De cara al hiato no se trataría, en fin, de señalar el manto de invisibilidad y reclamar que se lo quite, para que entonces sí resurgiera prístina la verdad originaria. Exhumar fotografías de esas largas décadas y mostrarlas no resuelve el problema. En todo caso, allí apenas comienza. ¿Qué es lo que mostrarían esas imágenes?, ¿a quiénes mostrarían? ¿Cómo reponer las imágenes de indígenas en la historia argentina sin pretender reponer una continuidad, un encadenamiento sin sobresaltos? ¿Con qué imágenes, entonces, mostrar las continuidades y también las discontinuidades?, ¿cómo evitar el simple "ahora hay" sin caer en el también simple "siempre hubo"?, ¿cómo mostrar lo que no se nombra o lo que es nombrado de diferentes maneras, si "Io" que es nombrado y mostrado de diferentes maneras cambia de acuerdo con esos modos de nombrar y mostrar? ¿Cómo ofrecer en una historia imágenes que repongan la existencia por debajo de la negación, pero que a la vez muestren la negación?, ¿qué imágenes podrían mostrar el hiato mismo, los cortes, los olvidos y los opacamientos? 


\section{Conclusiones prospectivas}

Intenté mostrar la relevancia de estudiar la racialización y la raza en los imaginarios para comprender los procesos de reproducción y persistencia de las desigualdades sociales, tanto como las búsquedas de reducirlas y las disputas en torno a ellas. El camino para ello fue profundizar en los procesos de clasificación social, acudiendo a algunas propuestas teóricas y proponiendo un análisis concreto. Esto implicó la revisión de algunos aportes de la perspectiva decolonial y la crítica de algunas derivaciones y ampliaciones que esa red de reflexiones genera en su expansión contemporánea. No reiteraré aquí esas críticas a la deriva esencialista, sino que ofreceré algunas pistas conceptuales positivas para continuar los estudios críticos de la racialización y la raza en la región y en Argentina, y de los procesos de clasificación social, en general.

Son indudables los aportes del grupo modernidad / colonialidad, y en especial de Aníbal Quijano, para pensar desde América Latina las dinámicas de la racialización e iluminar zonas oscuras de las teorías eurocéntricas al respecto. Este horizonte de trabajo permanece incitante, particularmente si se asume como punto de partida la vacuidad de la raza, su inestabilidad y sus potencialidades y articulaciones múltiples (de la Cadena, 2008), y se acepta el desafío de especificar las formas que asume o asumió en distintos contextos históricos, sociales, económicos y culturales, como hiciera Poole, por ejemplo, con los aportes reseñados someramente en la nota 9 de este artículo. Tomar en serio la idea de que "las definiciones de raza son dialógicas" (de la Cadena, 2008), por lo demás, implica que la especificación y contextualización de sus formas concretas releve los intercambios en los campos científicos y académicos, tanto como los que se dan en otros ámbitos y a diversa escala entre agentes políticos y estatales, organizaciones y movimientos sociales, organismos internacionales, actores religiosos, etcétera.

De igual modo, las articulaciones múltiples y las especificidades sociohistóricas de la raza y la racialización podrían llevarnos a perder de vista lo que de común pudieran tener esas multiplicidades. Ciertamente, es ante conceptos "precisos" de "raza" que más tarde o más temprano recurren a concepciones ahistóricas del cuerpo o la biología, que algunos autores hicieron hincapié en su variabilidad. Arias y Restrepo aceptan el reto de pensar, de manera conceptual, las continuidades y discontinuidades en las genealogías de la racialización y parten de notar precisamente el consenso académico acerca de que las mencionadas articulaciones múltiples de "raza" han desbordado y desbordan los límites del racismo científico de finales del siglo XIX y comienzos del XX. Pero entonces, ¿cuál sería la particularidad de la "raza" y la racialización (y del racismo) que permitiría reconocer que esas articulaciones diversas corresponden a una zona común? Arias y Restrepo recuperan la idea de Foucault de que el régimen de poder de la biopolítica, que comienza a configurarse en el siglo XVIII, produce a la población como su objeto, y que el bienestar de -o 
simplemente el hacer vivir a- la propia población supone para los Estados "un exterior de seres humanos dispensables que se pueden dejar morir o, incluso, hacer morir" (Arias y Restrepo, 2010, p. 57). En este punto

puede establecerse la singularidad de la racialización, sin por ello limitar sus múltiples articulaciones en conceptualizaciones de raza. La racialización apuntaría a ese proceso de marcación-constitución de diferencias en jerarquía de poblaciones (en el sentido foucaultiano) a partir de diacríticos biologizados que apelan al discurso experto, e independientemente de que su inscripción sea en el cuerpo-marcado o en el sujeto moral, pero siempre apuntando a la gubernamentalización de la existencia de las poblaciones así racializadas (Arias y Restrepo, 2010, p. 58).

Arias y Restrepo extraen de estas consideraciones tres aspectos interrelacionados que creo pueden funcionar como analizadores de articulaciones raciales específicas: por un lado, la distinción u oposición de dos entidades: una física o material y otra como el alma, la mente o la razón, por otro lado, la centralidad de la primera de estas dimensiones en su capacidad para definir o determinar a la segunda, en especial desde el siglo XIX y, por último, la aprehensión de esa faceta física o material en términos biológicos, i. e., de leyes y operaciones científicas que se aplican al ámbito "natural" en general.

Si pudiéramos continuar con el análisis del hiato y de las imágenes históricas en la racialización del pasado y el presente argentinos, el reto residiría en reconstruir estas formas específicas en que la "raza" participa del imaginario, tanto allí donde "raza" opera como subterfugio para legitimar asimetrías o exclusiones y negaciones, como donde opera como fundamento de reivindicaciones o demandas, y la especificación debería alcanzar también a las propias categorías analíticas.

Además, en cada momento y lugar los sistemas de clasificación racial conviven, a veces se superponen y traslapan, y casi nunca se diferencian de manera clara y distinta. Por ejemplo, a propósito de las categorías censales en Argentina, Otero (1998) mostró su papel en la "desaparición estadística" de indígenas y negros/as a finales del siglo XIX. La armazón censal de aquel sistema estadístico licuó la presencia indígena y negra, al tiempo que promovió la exaltación del papel de los inmigrantes transatlánticos. Las preguntas sobre raza y color, presentes en la grilla colonial, fueron suprimidas de la grilla liberal "igualitaria y objetiva" (Otero, 1998, p. 148). Estas decisiones técnicas y la consecuente desaparición estadística de "indios" y "negros" se sostenían en las orientaciones ideológicas de la elite intelectual y del sistema censal de entonces. Así, la grilla liberal no discriminaba en el plano matricial, es decir, en el relevamiento y la cuantificación de los datos, y era interpretada en clave jerárquica y evolucionista al ser elaborados los análisis y comentarios de los 
datos, donde se hablaba en términos de "razas", exponiendo las virtudes de la "caucásica o europea" y su superioridad biológica y moral sobre la indígena y la negra ${ }^{15}$ (Otero, 1998). La historia reciente de las categorías censales muestra otro momento de cambio significativo. Como indiqué, en el Censo Nacional de Población de 2001 el Estado argentino incorporó la temática indígena y realizó en 2004-2005 una Encuesta Complementaria de Pueblos Indígenas. Por su parte, algunas organizaciones negras consiguieron que en 2005 se hiciera una prueba piloto en un barrio de Buenos Aires y en otro de la ciudad de Santa Fe con el fin de testear la posible interrogación sobre afrodescendencia (Frigerio, 2008), que se efectivizó en el censo nacional de 2010.

El ejemplo podría extenderse más allá y al lado de las categorías censales, incluyendo la dinámica histórica de las categorías sociales en otras instituciones estatales y no estatales, en distintos sectores sociales y producciones culturales. Vimos que es precisamente cuando el criterio racial de clasificación social es abandonado en el registro censal que sus categorías sobreviven de diversas maneras para negar que en Argentina existan quienes podrían incluirse en algunas de ellas, como "negros" o "indios". Por lo demás, la literatura y la música (vgr. tangos y algunos ritmos de música folklórica, por elegir géneros prototípicos), continuaron echando mano de este tipo de categorías hasta nuestros días, tal como sucede en el habla coloquial y los insultos callejeros, o los estilizados en espacios privilegiados para ello como los estadios de fútbol, que producen y reproducen a diario términos y conceptos raciales y racistas.

La clave está en que los sistemas clasificatorios no se sustituyen total y absolutamente, quedando unos abandonados de manera definitiva y surgiendo otros para ocupar el lugar dejado libre por el anterior. Sistemas clasificatorios diferentes pueden funcionar simultáneamente (Caggiano, 2012). Es de cara a estas composiciones y fusiones de sistemas y categorías no necesariamente coherentes y con temporalidades diversas que organizaciones indígenas como las analizadas procuran elaborar sus propuestas alternativas, y es en ese marco que enfrentan las dificultades reseñadas.

Como ya se vislumbra, la complejidad de la situación es todavía mayor porque no son solo los sistemas de clasificación racial los que coexisten, se amalgaman o fusionan, sino los sistemas (abiertos y en proceso) de clasificación social en general. Cuando señalé que, siempre dentro de determinadas coordenadas culturales, una imagen como la del "cacique mataco" de la figura 7 podía mostrar "muchas cosas juntas", anticipaba precisamente esta idea de la yuxtaposición y coexistencia de sistemas de clasificación social, que articulan no solamente diversas categorías raciales, sino a ellas con categorías de clase, étnicas, regionales, generacionales, políticas, de género, entre otras. Los sistemas clasificatorios operan de manera compuesta, pudiendo producir diferentes

15 Ver también, para el caso particular de la población negra en los censos y las categorías raciales, Frigerio (2006). 
retroalimentaciones entre, por ejemplo, raza, clase social y afiliación política. Se ha indicado que en Argentina tuvo lugar tempranamente un proceso de "racialización de las relaciones de clase" (Margulis, 1998). Esta fórmula funciona mejor en conjunto con la de un "enclasamiento de las relaciones raciales, i.e., racializadas". Los dos sintagmas juntos dan mejor cuenta de la articulación de relaciones raciales y de clase. Si "racialización de las relaciones de clase" permite comprender que todo trabajador visto "desde arriba" pueda ser un "negro de mierda" o los trabajadores en su conjunto, asociados a movimientos sindicales o políticos (el peronismo, por antonomasia), hayan sido vistos por las elites y parte de las clases medias como "la negrada", "la indiada" o los "cabecitas negras", "enclasamiento de las relaciones raciales" permite observar el hecho de que diferentes estigmas que pesan sobre la población "no blanca" contribuyen a mantener sus posiciones subalternas.

Cabe concluir con una cita de Quijano, porque justo sobre este punto el autor ofrece agudas sugerencias, reunidas en la idea de la "heterogeneidad de la clasificación social", o de los "procesos de clasificación, des-clasificación y re-clasificación social de una población" (Quijano, 2000a, p. 369). Es inconducente -afirma Quijano- asumir que las gentes, solo por ocupar determinados lugares y ejercer ciertos roles constituyan una comunidad o un sujeto histórico.

Las gentes pueden tener, por ejemplo, un lugar y un papel respecto del control del trabajo y otro bien diferente y hasta opuesto respecto del control del sexo o de la subjetividad, o en las instituciones de autoridad. Y no siempre los mismos en el curso del tiempo (Quijano, 2000a, p. 369).

No hay tal sujeto cerrado, constituido en torno a un eje de diferencia o desigualdad, porque estas "gentes" cambian y pueden modificar su lugar y su papel en un patrón de poder, y porque este patrón está siempre -con intensidades variables- puesto en cuestión. En estas sugerencias de Quijano, alejadas de cualquier rastreo de un origen, en su apelación a la historia como proceso y al estudio de la historia como especificación de condiciones concretas de configuración de las relaciones sociales, pueden hallarse las precauciones necesarias para evitar la deriva esencialista. "Toda posible teoría de la clasificación social de las gentes requiere, necesariamente, indagar por la historia, las condiciones y las determinaciones de una dada distribución de relaciones de poder en una sociedad" (Quijano, 2000a, p. 368).

\section{Referencias}

Appadurai, Arjun. (2001). La modernidad desbordada. Dimensiones culturales de la globalización. Buenos Aires: Trilce/Fondo de Cultura Económica.

Arendt, Hannah. (1973). The Origins of Totalitarianism. New York: H. Brace. 
Arias, Julio \& Restrepo, Eduardo. (2010). Historizando raza: propuestas conceptuales y metodológicas. Crítica y Emancipación, (3), 45-64.

Balibar, Etienne \& Wallerstein, Immanuel. (1994). Raza, Nación y Clase. México: lepala.

Balibar, Etienne. (2003a). Un nouvel antisémitisme? Wiener Zeitschrift zur Geschichte der Neuzeit, (3), 109-113.

Balibar, Etienne. (abril 2003b). Election/Sélection. En Coloquio Traces. Race, Deconstruction, and Critical Theory. Universidad de California.

Balibar, Etienne. (marzo 2004). Différence, altérité, exclusion. Trois catégories anthropologiques pour théoriser le racisme. En Colloque International Discriminations sociales et discriminations génétiques: enjeux présents et à venir. Université Laval, Quebec.

Banton, Michael. (1977). The idea of race. Londres: Tavistock.

Barthes, Roland. (2005). La cámara lúcida. Nota sobre la fotografía. Buenos Aires: Paidós.

Baczko, Bronislaw. (1999). Los imaginarios sociales: memorias y esperanzas colectivas. Buenos Aires: Nueva Visión.

Bourdieu, Pierre. (1982). Ce que parler veut dire. L'économie des échanges linguistiques. París: Fayard.

Bourdieu, Pierre. (1990). Sociología y Cultura. México: Consejo Nacional para la Cultural y las Artes/Grijalbo.

Briones, Claudia \& Díaz, Raúl. (2000). La nacionalización/provincialización del "desierto". Procesos de fijación de fronteras y de constitución de "otros internos" en el Neuquén". En VVAA, V Congreso Argentino de Antropología Social. Parte 3, 44-57. La Plata: Entrecomillas impresores.

Briones, Claudia. (1997). Mestizaje y blanqueamiento como coordenadas de aboriginalidad y nación en Argentina. Mimeo.

Briones, Claudia. (1998). La alteridad del "Cuarto Mundo". Una reconstrucción antropológica de la diferencia. Buenos Aires: Ediciones del Sol.

Butler, Judith. (2000). El marxismo y lo meramente cultural. New Left Review, 2, 109-121.

Caggiano, Sergio. (2012). El sentido común visual. Disputas en torno a género, "raza" y clase. Buenos Aires: Miño y Dávila editores. 
Caggiano, Sergio. (2013). La visión de la «raza». Apuntes para un estudio de la fotografía de tipos raciales en Argentina. Revista del Museo de Antropología-UNC, 6, 107-118.

Canessa, Andrew. (2012). Conflict, Claim and Contradiction in the New Indigenous State of Bolivia. Working Paper Series, (22). Recuperado de http:// www.iai.spk-berlin.de/fileadmin/dokumentenbibliothek/desigualdades/ workingpapers/WP_22_Canessa_online.pdf

Castro-Gómez, Santiago \& Grosfoguel, Ramón (eds.). (2007). El giro decolonial. Reflexiones para una diversidad epistémica más allá del capitalismo global. Bogotá: lesco-Pensar-Siglo del Hombre Editores.

De la Cadena, Marisol. (2008). Formaciones de indianidad. Articulaciones raciales, mestizaje y nación en América Latina. Lima: Envión editores.

Douglas, Mary \& Hull, David (eds.). (1992). How Classification Works. Nelson Goodman among the Social Sciences. Edinburgh: Edinburgh University Press.

Edwards, Elizabeth. (1992). Anthropology and Photography. 1860-1920. New Haven and London: Yale University Press and The Royal Anthropological Institute.

Edwards, Elizabeth. (1996). Antropologia e fotografia. Cadernos de Antropologia e Imagem, (3), 11-28.

Escobar, Arturo. (2003). Mundos y conocimientos de otro modo: el programa de investigación de modernidad/colonialidad Latinoamericano. Tabula Rasa, (1), 51-86.

Foucault, Michel. (1996). Genealogía del Racismo. La Plata: Altamira.

Fraser, Nancy. (1997). Justice Interruptus. Nueva York: Routledge.

Fraser, Nancy. (2000). Heterosexismo, falta de reconocimiento y capitalismo: una respuesta a Judith Butler. New Left Review, 2, 123-134.

Fraser, Nancy y Axel Honneth. (2003). Redistribution or Recognition? Nueva York: Verso.

Frigerio, Alejandro. (2006). "Negros" y "Blancos" en Buenos Aires: Repensando nuestras categorías raciales. Temas de Patrimonio Cultural, (16), 77-98.

Frigerio, Alejandro. 2008. De la «desaparición» de los negros a la «reaparición de los afrodescendientes: Comprendiendo la política de las identidades negras, las clasificaciones raciales y de su estudio en la Argentina". En Gladys Lechini (comp.), Los estudios Afroamericanos y Africanos en 
América Latina: Herencia, presencia y visiones del otro. Buenos Aires y Córdoba: CLACSO y CEA.

Gramsci, Antonio. (1985). Introducción a la filosofía de la praxis. Buenos Aires: Premiá Editora.

Guber, Rosana. (1997). Reflexiones sobre algunos usos nacionales de la Nación. Causas y Azares, (5), 59-66.

Guillamin, Colette. (1992). Sexe, Race et Pratique du pouvoir. L'idée de Nature. París: Côté-femmes.

Guillamin, Colette. (2002). L'idéologie raciste. Genèse et langage actuel. Paris: Gallimard.

Hall, Stuart. (1998). El problema de la ideología: marxismo sin garantías. DOXA, (18), 3-16.

Hall, Stuart. (2003). Da diáspora. Identidades e Mediações Culturais. Belo Horizonte: Ed. UFMG.

Hall, Stuart. (2000). Conclusion: The multi-cultural question. En Barnor Hesse (ed.), Un/settled Multiculturalisms: Diasporas, Entanglements, Transruptions. Londres: Zed Books, pp. 209-241.

Harrison, Faye. (1995). The persistent power of "race" in the cultural and political economy of racism. Annual Review of Anthropology, 24, 47-74.

Honneth, Axel. (1995). The Struggle for Recognition. Cambridge: The MIT Press.

Hund, Wulf. (2003). Inclusion and Exclusion: Dimensions of Racism. Wiener Zeitschrift zur Geschichte der Neuzeit, (3), 3-19.

Kropff, Laura. (2005). Activismo Mapuche en Argentina. Trayectoria histórica y nuevas propuestas. En Pablo Dávalos (comp.), Pueblos indígenas, estado y democracia, Buenos Aires: Consejo Latinoamericano de Ciencias Sociales.

Malik, Kenan. (1996). The Meaning of Race. Race, History and Culture in Western Society. Londres: Mac Millan.

Margulis, Mario. (1998). La "racialización” de las relaciones de clase. En Mario Margulis, Marcelo Urresti, et al. (eds.), La segregación negada. Cultura y discriminiación social. Buenos Aires: Biblos.

Ortner, Sherry. (2006). Anthropology and Social Theory. Culture, Power, and the Acting Subject. Durham and London: Duke University Press.

Otero, Hernán. (1998). Estadística censal y construcción de la nación. El caso argentino, 1869-1914. Boletín del Instituto de Historia Argentina y Americana "Dr. Emilio Ravignani”, (16 y 17), 123-149. 
Penhos, Marta Noemí. (2005). Frente y perfil. Una indagación acerca de la fotografía en las prácticas antropológicas y criminológicas en Argentina a fines del siglo XIX y principios del XX. En VVAA, Arte y antropología en la Argentina. Buenos Aires: Fundación Espigas.

Perfil. (28 julio 2007). Insulto a ministra boliviana: Aníbal Fernández pide sanción. En Perfil, Buenos Aires.

Poole, Deborah. (2000). Visión, raza y modernidad. Una economía visual del mundo andino de imágenes. Lima: Sur Casa de Estudios del Socialismo y Consejería en Proyectos.

Quijano, Aníbal. (1999). ¡Qué tal raza! Ecuador Debate, (48), 141-152.

Quijano, Aníbal. (2000a). Colonialidad del poder y clasificación social. Journal of World-System Research, 11(2), 342-386.

Quijano, Aníbal. (2000b). Colonialidad del poder, eurocentrismo y América Latina. En Edgardo Lander (ed.), La Colonialidad del saber: Eurocentrismo y Ciencias Sociales. Perspectivas Latinoamericanas. Caracas: Consejo Latinoamericano de Ciencias Sociales.

Quijano, Aníbal. (2008). El trabajo al final del Siglo XX. Ecuador Debate, (74), 187-204.

Quijano, Aníbal. 2014 (1993). “Raza”, "etnia” y "nación” en Mariátegui. Cuestiones abiertas. En Aníbal Quijano. Buenos Aires: Consejo Latinoamericano de Ciencias Sociales.

Restrepo, Eduardo \& Rojas, Axel. (2010). Inflexión decolonial: fuentes, conceptos y cuestionamientos. Popayán: Instituto de Estudios Sociales y Culturales Pensar-Maestría en Estudios Culturales, Universidad Javeriana-Editorial Universidad del Cauca.

Segato, Rita Laura. (2010). Los cauces profundos de la raza latinoamericana: una relectura del mestizaje. Crítica y Emancipación, (3), 11-44.

Segato, Rita. (1997). Identidades políticas/ alteridades históricas: una crítica a las certezas del pluralismo global. Anuario Antropológico, 97, 161-196.

Smith, Shawn Michelle. (1999). American Archives. Gender, Race, and Class in Visual Culture. New Jersey: Princeton University Press.

Smith, Shawn Michelle. (2004). Photography on the Color Line. W.E.B. Du Bois, Race, and Visual Culture. Durham \& London: Duke University Press.

Starr, Paul. (1992). Social Categories and Claims in the Liberal State. En Mary Douglas y David Hull (eds.), How Classification Works. Nelson Goodman among the Social Sciences. Edinburgh: Edinburgh University Press. 
Stocking Jr., George W. (1968). Race, Culture and Evolution. Essays in the History of Anthropology. New York: The Free Press.

Stolcke, Verena. (1992). Racismo y sexismo en la Cuba colonial. Madrid: Alianza Editorial.

Stolcke, Verena. (1995). Talking culture. New boundaries, new rhetorics of exclusion in Europe. Current Anthropology, 36(1), 1-24.

Stolcke, Verena. (1999). ¿Es el sexo para el género como la raza para la etnicidad? Cuadernos para el Debate, (6), 1-32.

Thompson, Edward Palmer. (1989). La formación de la clase obrera en Inglaterra. Barcelona: Crítica.

Tilly, Charles. (2000). La desigualdad persistente. Buenos Aires: Manantial.

Todorov, Tzvetan. (2000). Nosotros y los Otros. México: Siglo XXI.

Williams, Raymond. (2000). Marxismo y Literatura. Barcelona: Península/Biblos.

Wolf, Eric. (2000) [1982]. Europa y la gente sin historia. México: Fondo de Cultura Económica.

Young, Iris Marion. (1990). Justice and the Politics of Difference. Princeton: Princeton University Press. 